\title{
Optimal Control Theory for Undergraduates
}

\author{
Ernst Juerg Weber \\ School of Economics and Commerce \\ University of Western Australia \\ Crawley WA 6009 \\ eweber@ecel.uwa.edu.au
}

January 2005

\begin{abstract}
Dynamic optimization is widely used in financial economics, macroeconomics and resource economics. This is accounting for some tension between the undergraduate and graduate teaching of economics because most undergraduate programs still concentrate on static economic analysis. This paper shows how, with the help of the Microsoft Excel Solver tool, the principles of dynamic economics can be taught to students with minimal knowledge of calculus. As it is assumed that the reader has no prior knowledge of optimal control theory, some attention is paid to the main concepts of dynamic optimization.
\end{abstract}

JEL Classification: A22, C61, D91, D92, Q00

This paper was first presented at the Economic Education Conference at the University of South Australia in July 2004, and in an Economics seminar at the University of Western Australia. The author is indebted to the participants for their comments. 
Dynamic economic analysis emerged more than half a century ago. Ramsey (1928) analyzed the consumption-saving decision, and Hotelling (1931) showed how an exhaustible resource is optimally managed. Allen (1938) included a chapter on the calculus of variations in his textbook on mathematical economics, which was used by a generation of graduate students. After World War II, the tools of dynamic programming and optimal control theory, which were developed by applied mathematicians, became available to economists. Today, dynamic optimization is widely used in financial economics, macroeconomics and resource economics. This is accounting for some tension between the undergraduate and graduate teaching of economics because most undergraduate programs still concentrate on static economic analysis. This paper shows how, with the help of the Microsoft Excel Solver tool, the principles of dynamic economics can be taught to students with minimal knowledge of calculus. Unlike in Nævdal (2003), it is assumed that the reader has no prior knowledge of optimal control theory. Therefore, some attention is paid to the main concepts of dynamic optimization. Section 1 reviews the history of dynamic optimization. Section 2 discusses some problems that are drawn from resource economics. Section 3 presents worksheets for the optimal management of a nonrenewable resource and the consumption-saving decision in macroeconomics. The examples in Section 2 and the analytical solution in Section 4 highlight the connection between optimal control theory and the valuation of assets in financial economics.

The management of natural resources is attracting much student interest. At the same time, the increased sophistication in the teaching of finance in business schools, a process that started in the 1970s, has made students receptive to arguments that stress the consequences of economic decisions on the future. These developments are creating an opportunity for economics lecturers, who should find ways to overcome the artificial barrier between static undergraduate economics and dynamic graduate economics. This would make research in financial economics, macroeconomics and resource economics more accessible to the majority of students who finish 
with a Bachelor degree, and it would make it easier for students to enter graduate programs in economics. The huge research effort in dynamic economics that occurred during the past two decades goes largely unnoticed in the economic policy debate because undergraduate curricula fail to expose future policy makers, whose economics education rarely exceeds the undergraduate level, to dynamic economic analysis. This is not the first paper that attempts to popularize optimal control theory. Dorfman (1969) was highly successful in introducing graduate students to optimal control theory. The present paper attempts to popularize dynamic economic analysis to undergraduate economics. This step has become feasible because most students know how to use Microsoft Excel, and the Excel Solver tool provides a convenient way to solve dynamic problems numerically.

\section{$\underline{1 .}$ History of Dynamic Optimization}

The early research on dynamic optimization applied the calculus of variations, which had emerged in the $18^{\text {th }}$ and $19^{\text {th }}$ centuries. Unlike in standard calculus, where the value of a function depends on the value of the independent variable, in the calculus of variations the value of a 'function' depends on the form or shape of another function. The calculus of variations is much harder than standard calculus because it is more difficult to find the optimal form of an entire function than the optimal value of a variable. In Ramsey's consumption-saving model, the consumer's life-time utility depends on the time path of consumption. The goal of dynamic optimization is to find the time path of consumption that maximizes the consumer's life-time utility. In Hotelling's model of exhaustible resources, dynamic optimization yields the time path of resource extraction that maximizes the value of a resource project, for example a mine. Usually, in economics and finance, an optimal path is sought that represents the decision variable 
as a function of time. But the calculus of variations is also used in engineering and physics, where the optimal path may have a physical dimension. ${ }^{1}$

In the 1950s, Richard Bellman became interested in numerical solutions to dynamic optimization problems. In his autobiography he writes:

"... as of 1954 or so I had stumbled into some important types of problems and had been pushed, willy-nilly, into answering some significant kinds of questions. I could handle deterministic control processes to some extent and stochastic decision processes in economics and operations research as well. Where next? At this point, I began to think in a logical fashion, using a systematic methodological approach." (Bellman 1984, p. 182)

Richard Bellman and Stuart Dreyfus also convey:

"In 1955, we began a systematic study of the computational feasibility of dynamic programming. We collected a number of optimization problems from many different fields and applied our methods in many different ways." (Bellman and Dreyfus 1962, p. viii)

This work led to the publication of Dynamic Programming by Bellman in 1957 and Applied Dynamic Programming (co-authored with S.E. Dreyfus) in $1962 .^{2}$ In the same year, L.S. Pontryagin and his students - V.G. Boltyanskii, R.V. Gamkrelidze, and E.F. Mishchenko published their pioneering research on optimal control theory in The Mathematical Theory of Optimal Processes (first published in Russian in 1961).

In the calculus of variations the decision maker has direct control of the so-called state variable. For example, the operator of a mine decides on the amount of ore to be extracted. The mine's ore reserve is the state variable and the rate of ore extraction is the control or decision variable. There exists a one-to-one relationship between the decision variable and the state variable because the rate of extraction determines the reduction in the ore reserve at each point in

\footnotetext{
${ }^{1}$ The first problem in the calculus of variations was the so-called brachistochrone problem, which was formulated by Galileo in 1630 and solved by James and John Bernoulli in the 1690s. Galileo sought the form of a path along which a ball would roll downward, traversing a given horizontal distance, in the shortest possible time. The Bernoulli brothers found the exact path, which is first steep and then flat.

2 See also Dreyfus (2002).
} 
time. The direct control of the state variable through the decision maker is specific to the calculus of variations. Optimal control theory considers a more general situation in which the change in the state variable depends both on the decision variable and the level of the state variable. This links decisions across time because the current decision affects the level of the state variable in the future. The state variable provides a channel through which the current decision impacts the future growth of the state variable. Bellman quickly learned that it is difficult, and indeed often impossible, to solve optimal control problems with the calculus of variations. In his autobiography, he reminisces:

"... I started work on optimal control theory. I had seen problems in economics and operations research ... The tool we used was the calculus of variations. What we found was that very simple problems $r$ equired great ingenuity. A small change in the problem caused a great change in the solution. ... Clearly, something was wrong. There was an obvious lack of balance. Reluctantly, I was forced to the conclusion that the calculus of variations was not an effective tool for obtaining a solution." (Bellman 1984, p. 175)

For this reason, Bellman developed dynamic programming, which solves optimal control problems numerically. Still, it took him some time to realize that dynamic programming is a numerical method to solve optimal control problems.

"... I should have seen the application of dynamic programming to control theory several years before. I should have, but I didn't. ... Scientific developments can always be made logical and rational with sufficient hindsight. It is amazing, however, how clouded the crystal ball looks beforehand." (Bellman 1984, p. 182)

\section{Examples in Resource Economics}

The new concepts that have been introduced so far will now be repeated with the help of two examples, the optimal management of a mine and of a fishery. In dynamic optimization the value of a 'function' depends on the entire form of another function. A 'function' whose value depends on the form of another function is called a functional. Functionals play an important role 
in financial economics because an asset embodies a stream of expected cash flows, which can be represented as a function of time.

A mine is an asset whose value at time 0 equals the present value of the stream of cash flows that will be earned during the mine's life, say until time $T$ :

$$
V\left(x_{0}, \vec{u}\right)=\int_{0}^{T} C(u(t)) e^{-r t} d t
$$

The cash flow function, $C(u(t))$, indicates that extracting the amount of ore, $u(t)$, produces the cash flow, $C(u(t))$, at time $t$. It is assumed that ore extraction is subject to diminishing returns at each point in time. Cash flows that occur in the future are discounted by the discount factor $e^{-r t}$, where $r$ is the discount rate applicable to this type of investment. The value of the mine, $V\left(x_{0}, \vec{u}\right)$, which is its price in an efficient equity market, depends on the initial ore reserve, $x_{0}$, and on the time path of ore extraction, $\vec{u}$, in the interval from 0 to $T$. The time path of ore extraction matters because future cash flows are discounted, and ore extraction is subject to diminishing returns at each point in time. The discount factor provides an incentive to mine the ore quickly, but this effect is counterbalanced by the need to spread the ore production over time because the cash flow function is subject to diminishing returns. The value of the mine, $V\left(x_{0}, \vec{u}\right)$, is a functional because it depends on the form of a function, the time path of ore extraction, $\vec{u}$, during the mine's life.

The ore reserve, $x(t)$, is the state variable and the rate of extraction, $u(t)$, is the decision variable. At each point in time, the rate of extraction, $u(t)$, determines the reduction in the ore reserve:

$$
\frac{d x}{d t}=-u(t)
$$


The decision maker directly controls the variation in the state variable, $d x / d t$, by setting the control variable, $u(t)$. The standard behavioral hypothesis is that the owner of the mine chooses the optimal time path of ore extraction, $\vec{u}$, that maximizes the value of the mine, $V\left(x_{0}, \vec{u}\right)$. A dynamic optimization problem in which the decision maker has direct control of the state variable can be solved with the calculus of variations.

The second example concerns the optimal management of a fishery, which has become an important policy issue because of the overexploitation of world fish stocks. Suppose it is possible, through an international treaty, to assign a certain fish stock to a single decision maker who wishes to maximize the value of the resource. The state variable is the stock of fish, $x(t)$, and the decision variable is the harvest, $u(t)$. The cost of fishing, $C$, depends positively on the harvest and negatively on the stock of fish: $C=C(u(t), x(t))$. The stock of fish is an argument in the cost function because it is easier to catch fish when fish are abundant. At each point in time, the cash flow equals revenue minus cost, $p u(t)-C(u(t), x(t))$, where it is assumed that the price of fish, $p$, is constant. The value of the fishery, its asset price, equals the present value of the stream of cash flows earned from fishing:

$$
V\left(x_{0}, \vec{u}\right)=\int_{0}^{\infty}[p u(t)-C(u(t), x(t))] e^{-r t} d t
$$

The value of the fishery, $V\left(x_{0}, \vec{u}\right)$, is a functional whose value depends on the initial stock of fish, $x_{0}$, and the time path of fishing, $\vec{u}$. The absence of a terminal date $T$ makes it possible that the fishery is operated on a sustainable basis, but it does not guarantee it. ${ }^{3}$ This problem generalizes the preceding problem in two ways. First, the state variable, the stock of fish, influences the cash flow through the cost of fishing. Second, the state variable is an argument in

\footnotetext{
${ }^{3}$ It is more likely that the fishery will be operated on a sustainable basis if the biological renewal is high and the discount rate is low.
} 
the dynamic constraint because a fishery is a renewable resource whose biological renewal depends on the stock of fish, $x(t)$. The biological renewal function, $f(x(t))$, reaches a maximum at some critical stock size were the conditions are most favorable for the survival of the fish. At each point in time, the growth rate of the fish stock is the difference between the biological renewal minus the catch:

$$
\frac{d x}{d t}=f(x(t))-u(t)
$$

Differential equation (4) is a dynamic constraint that determines the evolution of the stock of fish over time. It describes the management techniques available for fish stocks, including genetic improvements that raise the biological renewal. Wealth maximization implies that the decision maker chooses the time path of fishing, $\vec{u}$, that maximizes the functional, $V\left(x_{0}, \vec{u}\right)$, subject to the dynamic constraint (4). The inclusion of the stock of fish in the constraint introduces an intertemporal externality in the decision process. The current catch affects the future catch because the growth rate of the stock of fish depends on the time path of the stock of fish. Equation (4) fulfills the same purpose as equation (2), but only equation (4) is a true technological constraint that restricts the time path of the state variable. An optimization problem with a meaningful dynamic constraint gives rise to an optimal control problem.

\section{Numerical Solution}

Microsoft Excel provides a convenient teaching platform for an applied introduction to optimal control theory because most students know how to use a spreadsheet. Dynamic optimization problems can be solved with the Excel Solver tool, which is a free add-in to Excel. ${ }^{4}$

\footnotetext{
${ }^{4}$ Solver is part of Excel, but you probably need to install it. Select 'Add-Ins ...' in the Excel Tools menu, and click on 'Solver Add-in'. Then, Solver will appear in the Tools menu, where it can be
} 
Solver implements the Generalized Reduced Gradient Nonlinear Optimization Method, developed by Leon Lasdon and Allan Waren in the 1990s. More information on the algorithm can be found on the internet. ${ }^{5}$ This section presents two exercises: the first concerns the management of a mine and the second considers the consumption-saving decision in the Ramsey model.

Since analytical work is easier with continuous time than with discrete time, continuous time has been used so far and we will return to continuous time for the analytical solution in the next section. But for practical work it is necessary to switch to discrete time because it is not possible to record economic data continuously. With annual data, the time path of ore extraction is the mine's output in each year: $\vec{u}=\left\{u_{0}, u_{1}, u_{2} \ldots . u_{T}\right\}$. The value of the mine is the sum of discounted cash flows earned during its life, from year 0 to $T$.

$$
V\left(x_{0}, \vec{u}\right)=\sum_{t=0}^{T} \beta^{t} C\left(u_{t}\right)
$$

The present value (5) is the discrete time equivalent of equation (1). $C\left(u_{t}\right)$ indicates the cash flow in year $t$, and $\beta=1 /(1+r)$ is the discount factor, where $r$ is the interest rate appropriate for a resource project. It should be noted that summation becomes integration when moving from discrete time to continuous time. A numerical solution to the dynamic optimization problem requires that the annual cash flow function is specified. The cash flow can be modeled as a power function, $C\left(u_{t}\right)=u_{t}^{\alpha}$, which has diminishing returns if $0<\alpha<1$. Substituting into equation 5 yields:

started. If you have problems with the installation of Solver, search for 'load add-in' in the Excel Help facility.

${ }^{5}$ www.frontsys.com and www.solver.com include a tutorial, sample programs and upgrades to Solver. 


$$
V\left(x_{0}, \vec{u}\right)=\sum_{t=0}^{T} \beta^{t} u_{t}^{\alpha}
$$

The operator of the mine chooses the time path of ore extraction, $\vec{u}=\left\{u_{0}, u_{1}, u_{2} \ldots \ldots u_{T}\right\}$, that maximizes the present value functional, $V\left(x_{0}, \vec{u}\right)$, subject to:

$$
x_{t+1}-x_{t}=-u_{t}
$$

Like equation (2), equation (7) is not a true constraint that limits the rate of change of the ore reserve through some technological relationship. Equation (7) says that the decision maker controls the reduction in the ore reserve from one year to the next. Finally, a numerical solution to a dynamic optimization problem requires two endpoint conditions. Suppose the initial ore reserve is 1000 units and the mine's owner wants to operate the mine for 10 years. Then, the initial condition is $x_{0}=1000$, and the final condition is $x_{T}=x_{10} \geq 0$. Naturally, it is optimal to recover all ore because the value functional (6) assigns no value to ore that stays underground after time $T$. Therefore, the final condition holds as an equality, but it is sufficient to impose an inequality. In the case of a mine, it is also natural to assume that the rate of ore extraction is nonnegative at all times. Then, all elements of the so-called control set are nonnegative, or $\vec{u}=\left\{u_{t} \mid u_{t} \geq 0\right.$ for $\left.t=0 \ldots T\right\}$.

Worksheet 1.1 sets up the dynamic optimization problem of the mine. ${ }^{6}$ The parameter $\alpha$, which determines the curvature of the annual cash flow function is put at 0.8 , and the interest rate $r$ is eight percent. The formula in cell B3 converts the interest rate into the discount factor $\beta=1 /(1+r)$. Column $\mathrm{C}$ implements equation (7), which captures the time path of the ore reserve. At the beginning of each year, the ore reserve equals the reserve at the beginning of the preceding

${ }^{6}$ Conrad (1999) uses the Microsoft Excel Solver tool to solve many numerical allocation problems in resource economics. 
year minus the ore extracted during the preceding year, $x_{t+1}=x_{t}-u_{t}$. The initial ore reserve, which is shown in cell C6, is assumed to be 1000 units. Solver uses an iterative algorithm that requires an initial guess of the optimal time path of ore extraction. We first assume that ore is extracted evenly in each year, hence the value of 100 is included in cells B6 to B15. In the last column, $D C F(t)$ stands for the discounted cash flow earned from ore extraction in year $t, \beta^{t} u_{t}^{\alpha}$. Finally, cell D18 contains the value of the mine, $V\left(x_{0}, \vec{u}\right)$, which is the sum of discounted cash flows earned during its operation.

Worksheet 1.1

\begin{tabular}{|c|c|c|c|c|}
\hline & $\mathrm{A}$ & $\mathrm{B}$ & C & $\mathrm{D}$ \\
\hline 1 & $\alpha=$ & 0.8 & & \\
\hline 2 & $r=$ & 0.08 & & \\
\hline 3 & $\beta=$ & $=1 /(1+\$ \mathrm{~B} \$ 2)$ & & \\
\hline \multicolumn{5}{|l|}{4} \\
\hline 5 & Time & $\mathrm{u}(\mathrm{t})$ & $x(t)$ & $\mathrm{DCF}(\mathrm{t})$ \\
\hline 6 & 0 & 100 & 1000 & $=\left(\$ B \$ 3^{\wedge} \mathrm{A} 6\right)^{\star} \mathrm{B} 6^{\wedge} \$ \mathrm{~B} \$ 1$ \\
\hline 7 & 1 & 100 & $=\mathrm{C} 6-\mathrm{B} 6$ & $=\left(\$ B B 3^{\wedge A 7} 7\right)^{\star} \mathrm{B} 7^{\wedge} \$ B \$ 1$ \\
\hline 8 & 2 & 100 & $=\mathrm{C} 7-\mathrm{B} 7$ & $=\left(\$ B \$ 3^{\wedge} \mathrm{AB}\right)^{\star} \mathrm{B} 8^{\wedge} \$ \mathrm{~B} \$ 1$ \\
\hline 9 & 3 & 100 & $=\mathrm{C} 8-\mathrm{B} 8$ & $=\left(\$ B \$ 3^{\wedge} \mathrm{A9}\right)^{\star} \mathrm{B} 9^{\wedge} \$ \mathrm{~B} \$ 1$ \\
\hline 10 & 4 & 100 & $=\mathrm{C} 9-\mathrm{Bg}$ & $=\left(\$ B \$ 3^{n} \mathrm{~A} 10\right)^{*} \mathrm{~B} 10^{\wedge} \$ \mathrm{~B} \$ 1$ \\
\hline 11 & 5 & 100 & $=\mathrm{C} 10-\mathrm{B} 10$ & $=\left(\$ B \$ 3^{n} \mathrm{~A} 11\right)^{*} \mathrm{~B} 11 \wedge \$ \mathrm{~B} \$ 1$ \\
\hline 12 & 6 & 100 & $=\mathrm{C} 11-\mathrm{B} 11$ & $=\left(\$ B \$ 3^{\wedge} \mathrm{A} 12\right)^{*} \mathrm{~B} 12^{\wedge} \$ \mathrm{~B} \$ 1$ \\
\hline 13 & 7 & 100 & $=\mathrm{C} 12-\mathrm{B} 12$ & $=\left(\$ \mathrm{~B} \$ 3^{\wedge} \mathrm{A} 13\right)^{\star} \mathrm{B} 13^{\wedge} \$ \mathrm{~B} \$ 1$ \\
\hline 14 & 8 & 100 & $=\mathrm{C} 13-\mathrm{B} 13$ & $=\left(\$ B \$ 3^{n} \mathrm{~A} 14\right)^{*} \mathrm{~B} 14^{\wedge} \$ \mathrm{~B} \$ 1$ \\
\hline 15 & 9 & 100 & $=\mathrm{C} 14-\mathrm{B} 14$ & $=\left(\$ B \$ 3^{\wedge} \mathrm{A} 15\right)^{*} \mathrm{~B} 15^{\wedge} \$ \mathrm{~B} \$ 1$ \\
\hline 16 & 10 & & $=\mathrm{C} 15-\mathrm{B} 15$ & \\
\hline \multicolumn{5}{|l|}{17} \\
\hline 18 & & & PV & $=$ SUM(\$D\$6:\$D\$15) \\
\hline
\end{tabular}

Worksheet 1.2 shows the values that correspond to the formulas in worksheet 1.1 . Use the key combination $[\mathrm{Ctrl}][\sim]$ to switch back and forth between formulas and values. Here are some tips that will save you time. Write the number 0 into cell A6 and the number 1 into cell A7. Then, highlight both cells, click with the mouse on the lower right corner of cell A7, and drag the mouse downward. This yields the column with the years. Also write the number 100 into cell B6, click with the mouse on the lower right corner of the cell, and drag it downward to produce the initial time path of ore extraction. This even works with the formulas in columns $\mathrm{C}$ and $\mathrm{D}$. For example, write the formula into cell D6, click on the lower right corner of the cell, and drag it downward. As you can see, cell references that do not include \$ signs are updated, whereas cell 
references with $\$$ signs are not. This is important because $\$ \mathrm{~B} \$ 3$ and $\$ \mathrm{~B} \$ 1$ are fixed parameters, whereas the other cell references depend on the year $t$.

Worksheet 1.2

\begin{tabular}{|c|c|c|c|c|}
\hline & $\mathrm{A}$ & $\mathrm{B}$ & C & D \\
\hline 1 & $\alpha=$ & 0.8 & & \\
\hline 2 & $r=$ & 0.08 & & \\
\hline 3 & $\beta=$ & 0.9259 & & \\
\hline \multicolumn{5}{|l|}{4} \\
\hline 5 & Time & $\mathrm{u}(\mathrm{t})$ & $x(t)$ & $\mathrm{DCF}(\mathrm{t})$ \\
\hline 6 & 0 & 100 & 1000 & 39.81 \\
\hline 7 & 1 & 100 & 900 & 36.86 \\
\hline 8 & 2 & 100 & 800 & 34.13 \\
\hline 9 & 3 & 100 & 700 & 31.60 \\
\hline 10 & 4 & 100 & 600 & 29.26 \\
\hline 11 & 5 & 100 & 500 & 27.09 \\
\hline 12 & 6 & 100 & 400 & 25.09 \\
\hline 13 & 7 & 100 & 300 & 23.23 \\
\hline 14 & 8 & 100 & 200 & 21.51 \\
\hline 15 & 9 & 100 & 100 & 19.92 \\
\hline 16 & 10 & & 0 & \\
\hline \multicolumn{5}{|l|}{17} \\
\hline 18 & & & PV & 288.50 \\
\hline
\end{tabular}

The value of the mine, $V\left(x_{0}, \vec{u}\right)$, depends on the initial ore reserve, $x_{0}$, and on the time path of ore extraction, $\vec{u}$. Worksheet 1.2 shows that the value of the mine is 288.5 if the initial ore reserve is 1000 units and 100 units are extracted in each year. But an even time path is not optimal when future cash flows are discounted. Applying Solver yields the optimal time path of ore extraction that maximizes the value of the mine. To initiate Solver, click with the mouse on the target cell D18, which displays the value of the mine, and start Solver from the Tools menu. Dialog box 1 will appear.

\section{Dialog Box 1}

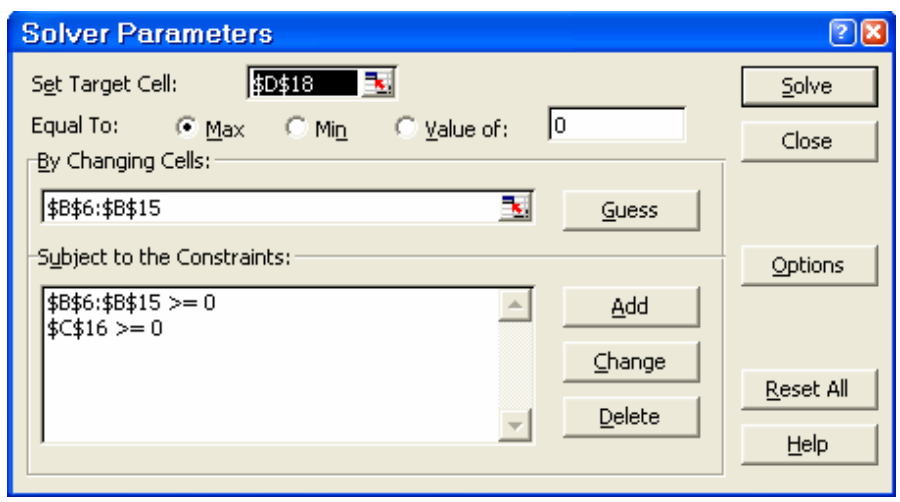


The top of the dialog box shows the target cell, whose value Solver maximizes. Write the range of cells with the time path of ore extraction, $\$ B \$ 6: \$ B \$ 15$, into the dialog box. Solver searches for the optimal values of cells B6 to B15 that maximize the value in the target cell D18, conditional on the constraints. The first constraint, $\$ B \$ 6: \$ B \$ 15>=0$, requires that ore extraction must be nonnegative in each year. Use the Add button to write this constraint into the dialog box; it cannot be done directly. The second constraint, $\$ C \$ 16>=0$, limits the maximum amount of ore that can be recovered during the mine's life to the initial ore reserve. When you have completed the dialog box, click on the Solve button in the top right corner.

Worksheet 2

\begin{tabular}{|r|r|r|r|r|r|}
\hline & \multicolumn{2}{|c|}{ A } & \multicolumn{1}{c|}{ B } & \multicolumn{1}{c|}{ C } & \multicolumn{1}{c|}{ D } \\
\hline 1 & $\alpha=$ & 0.8 & & \\
\hline 2 & $r=$ & 0.08 & & \\
\hline 3 & $\beta=$ & & 0.9259 & & \\
\hline 4 & & & & & \\
\hline 5 & Time & U(t) & $x(t)$ & DCF $(t)$ \\
\hline 6 & & 0 & 326.38 & 1000.00 & 102.56 \\
\hline 7 & & 1 & 222.13 & 673.62 & 69.80 \\
\hline 8 & & 2 & 151.18 & 451.50 & 47.50 \\
\hline 9 & & 3 & 102.89 & 300.32 & 32.33 \\
\hline 10 & & 4 & 70.02 & 197.44 & 22.00 \\
\hline 11 & & 5 & 47.66 & 127.41 & 14.98 \\
\hline 12 & & 6 & 32.43 & 79.76 & 10.19 \\
\hline 13 & & 7 & 22.07 & 47.32 & 6.94 \\
\hline 14 & & 8 & 15.02 & 25.25 & 4.72 \\
\hline 15 & & 9 & 10.22 & 10.22 & 3.21 \\
\hline 16 & & 10 & & $9.95 E-14$ & \\
\hline 17 & & & & & \\
\hline 18 & & & & PV & \\
\hline
\end{tabular}

Worksheet 2 shows the optimal time path of ore extraction. It is optimal to extract 326.4 units of ore in year 0, 222.1 units in year 1, 151.2 units in year 2, and so on. The value of the mine increases from 288.5 to 314.2 if the optimal time path of ore extraction is adopted. The optimal time path of ore extraction is downward sloping because the discount factor provides an incentive to get the ore out of the ground quickly. However, the diminishing returns of the annual cash flow function prevent that even more ore is mined in the early years. It should be noted that the optimal time path fulfills all constraints. In each year, ore extraction is nonnegative and ore 
extraction stops when the mine is exhausted. ${ }^{7}$ The entire ore reserve is extracted because no value is assigned to ore that stays underground at the end of the planning horizon.

A sensitivity analysis shows the influence of the interest rate on the optimal solution. Return to worksheet 1 , change the interest rate to ten percent in cell $\mathrm{B} 2$, highlight the target cell D18, and re-run Solver. Worksheet 3 shows the optimal time path of ore extraction with the higher interest rate. The rise in the interest rate increases the incentive to mine the ore quickly. Ore extraction increases to 382.3 units in year 0 and 237.4 units in year 1, afterwards less ore is extracted with the new interest rate of ten percent. The optimal time path of ore extraction is steeper because future cash flows are discounted more strongly. The value of the mine increases from 269.1 with even ore extraction to 304.5 with optimal extraction. The high discount rate explains why the value of the mine is now only 304.5 , even with optimal behavior. Still, worksheet 3 shows the best time path of ore extraction under the changed circumstances.

Worksheet 3

\begin{tabular}{|c|c|c|c|c|}
\hline & A & $B$ & C & D \\
\hline 1 & $\alpha=$ & 0.8 & & \\
\hline 2 & $r=$ & 0.1 & & \\
\hline 3 & $\beta=$ & 0.9091 & & \\
\hline \multicolumn{5}{|l|}{4} \\
\hline 5 & Time & $\mathrm{u}(\mathrm{t})$ & $x(t)$ & $\mathrm{DCF}(\mathrm{t})$ \\
\hline 6 & 0 & 382.34 & 1000.00 & 116.40 \\
\hline 7 & 1 & 237.40 & 617.66 & 72.28 \\
\hline 8 & 2 & 147.41 & 380.26 & 44.88 \\
\hline 9 & 3 & 91.53 & 232.86 & 27.87 \\
\hline 10 & 4 & 56.83 & 141.33 & 17.30 \\
\hline 11 & 5 & 35.29 & 84.50 & 10.74 \\
\hline 12 & 6 & 21.91 & 49.21 & 6.67 \\
\hline 13 & 7 & 13.61 & 27.30 & 4.14 \\
\hline 14 & 8 & 8.45 & 13.69 & 2.57 \\
\hline 15 & 9 & 5.25 & 5.25 & 1.60 \\
\hline 16 & 10 & & 0.00 & \\
\hline \multicolumn{5}{|l|}{17} \\
\hline 18 & & & PV & 304.45 \\
\hline
\end{tabular}

Two forces impact on the optimal timing of ore extraction. The discount factor makes it worthwhile to mine the ore quickly, but this effect is counterbalanced by the diminishing returns of the annual cash flow function. Worksheet 4 shows the optimal time path of ore extraction

${ }^{7} 9.95 \mathrm{E}-14=9.95 \times 10^{-14}$ is zero within the accuracy of Microsoft Excel. 
when the curvature of the cash flow function is less pronounced, implying a lower degree of diminishing returns. To this effect, the parameter $\alpha$ is changed from 0.8 to 0.9 in the initial worksheet 1 , and Solver is re-run. The optimal time path of ore extraction is now very steep: 537.0 units in year 0 , followed by 248.8 units in year 1, and 115.2 units in year 2.90 percent of all ore is mined during the first three years. The value of the mine increases from 457.3 with even ore extraction to 533.3 with optimal extraction. The increase in the value of the mine is larger than before because the low degree of diminishing returns of the annual cash flow function allows for a large deviation of the optimal time path of ore extraction from the even time path.

Worksheet 4

\begin{tabular}{|c|c|c|c|c|}
\hline & A & B & C & D \\
\hline 1 & $\alpha=$ & 0.9 & & \\
\hline 2 & $r=$ & 0.08 & & \\
\hline 3 & $\beta=$ & 0.9259 & & \\
\hline \multicolumn{5}{|l|}{4} \\
\hline 5 & Time & $u(t)$ & $x(t)$ & $\mathrm{DCF}(\mathrm{t})$ \\
\hline 6 & 0 & 537.04 & 1000.00 & 286.42 \\
\hline 7 & 1 & 248.76 & 462.96 & 132.67 \\
\hline 8 & 2 & 115.23 & 214.20 & 61.46 \\
\hline 9 & 3 & 53.37 & 98.97 & 28.46 \\
\hline 10 & 4 & 24.72 & 45.59 & 13.18 \\
\hline 11 & 5 & 11.45 & 20.87 & 6.11 \\
\hline 12 & 6 & 5.30 & 9.42 & 2.83 \\
\hline 13 & 7 & 2.46 & 4.12 & 1.31 \\
\hline 14 & 8 & 1.14 & 1.66 & 0.61 \\
\hline 15 & 9 & 0.53 & 0.53 & 0.28 \\
\hline 16 & 10 & & 0.00 & \\
\hline \multicolumn{5}{|l|}{17} \\
\hline 18 & & & PV & 533.33 \\
\hline
\end{tabular}

The second exercise concerns the Ramsey model, which plays a central role in advanced macroeconomics courses and macroeconomic research. The Ramsey model adds optimization behavior to the Solow-Swan model of economic growth by modeling the consumption-saving decision of a forward looking consumer. Blanchard and Fischer (1989, ch. 2) present the model with continuous time, and Walsh (2003, ch. 2) uses discrete time. We adopt discrete time because we are interested in numerical solutions of the optimal time paths of macroeconomic variables. This exercise is intended for students who are gaining a first exposure to dynamic macroeconomics. Readers who are not interested in macroeconomics can move directly to the 
analytic solution of optimal control problems in the next section, without loss of continuity of the argument.

The utility function of the representative consumer is:

$$
V\left(k_{0}, \vec{c}\right)=\sum_{0}^{T} \beta^{t} u\left(c_{t}\right)
$$

In year $t$, the consumer enjoys utility, $u\left(c_{t}\right)$, where $c_{t}$ is annual consumption. $\beta=1 /(1+\theta)$ is a subjective discount factor that uses the consumer's personal rate of time preference, $\theta$. The expression (8) measures the present value of lifetime utility of a consumer who expects to live for $T$ years, applying the subjective discount factor, $\beta$. A popular form of the annual utility function is the constant relative risk aversion utility function (CRRA), where $u\left(c_{t}\right)=\left(c_{t}^{1-\gamma}-1\right) /(1-\gamma)$. Substituting into equation (8) yields:

$$
V\left(k_{0}, \vec{c}\right)=\sum_{0}^{T} \beta^{t} \frac{c_{t}^{1-\gamma}-1}{1-\gamma}
$$

The parameter $\gamma$ determines the curvature of the annual utility function, $u\left(c_{t}\right)$. A high $\gamma$ indicates strongly diminishing marginal utility of annual consumption. Then, the intertemporal elasticity of substitution is low because shifting consumption from one year to the next reduces utility progressively in the first year, while utility rises only by a diminishing amount in the second. The present value of the consumer's lifetime utility is a functional, $V\left(k_{0}, \vec{c}\right)$, whose value depends on initial holdings of physical capital, $k_{0}$, and on the time path of consumption, $\vec{c}$, chosen by the consumer. Physical capital is the only form of wealth because net financial asset holdings are zero in a closed economy. 
Assume that individuals, who are both consumers and workers, produce output in accordance with the Cobb-Douglas production function. Since the Cobb-Douglas production function has constant returns to scale, it can be written in per capita terms:

$$
y_{t}=A k_{t-1}^{\alpha}
$$

Output per worker in year $t, y_{t}$, depends on the amount of physical capital per worker in the preceding year, $k_{t-1}$. The parameters $A$ and $\alpha$ determine the available technology. Equation (11), which is borrowed from the Solow-Swan model of economic growth, describes the mechanics of capital accumulation: ${ }^{8}$

$$
k_{t}=\left(A k_{t-1}^{\alpha}-c_{t}\right)+\frac{1-\delta}{1+n} k_{t-1}
$$

The bracket represents saving, which is output, $A k_{t-1}^{\alpha}$, minus consumption, $c_{t} . \delta$ is the depreciation rate of physical capital and $n$ is the rate of population growth, both measured in percent per year. Then, $((1-\delta) /(1+n)) k_{t-1}$ is the amount of capital per worker carried over from period $t-1$ into period $t$, taking account of depreciation and population growth. The difference equation (11) is a technological constraint that limits the availability of capital goods in each year. The amount of capital per worker increases if saving more than makes up for the reduction in capital per worker due to depreciation and population growth. The behavioral hypothesis is that the representative consumer chooses the time path of consumption that maximizes lifetime utility, subject to the dynamic constraint (11). At each point in time, the consumer faces an intertemporal trade-off because immediate consumption reduces future consumption by lowering capital accumulation and output growth.

\footnotetext{
${ }^{8}$ Walsh (2003, ch. 2) derives equation (11), which uses per capita terms, from a constraint with aggregate quantities.
} 
In the steady state, saving must equal $((n+\delta) /(1+n)) k^{*}$ to compensate for the negative effect of depreciation, $\delta$, and population growth, $n$, on the amount of capital per worker. To see this, set $k_{t}=k_{t-1}=k^{*}$ and solve for saving. Walsh (2003, ch. 2) also shows that the steady state amount of capital per worker is:

$$
k^{*}=\left[\frac{A \alpha(1+n)}{(1+n)(1+\theta)-(1-\delta)}\right]^{\frac{1}{1-\alpha}}
$$

The steady state output per worker, $y^{*}$, can be calculated by substituting $k^{*}$ into the production function (10), and the steady state consumption per worker, $c^{*}$, is output minus saving:

$$
c^{*}=A k^{* \alpha}-\frac{n+\delta}{1+n} k^{*}
$$

The curvature parameter of the annual utility function, $\gamma$, does not affect the steady state, but all other parameters matter.

The optimal response of the representative consumer to economic shocks determines the aggregate response of the economy. Starting from an initial steady state, the economy passes through a transition period until it reaches the new steady state. Strictly, it takes an infinite number of years until the economy reaches the new steady state, which is too much for the Solver algorithm to handle. However, using standard parameter values, the economy is very close to the new steady state within 20 years. Therefore, we calculate the optimal time paths of capital, output and consumption for a representative consumer with a time horizon of 20 years. ${ }^{9}$ Worksheet 5 sets up the optimal control problem of the representative consumer. Worksheet 5.1 includes the formulas and worksheet 5.2 shows the corresponding values. Remember that you can switch back and forth between formulas and values with the key combination $[\mathrm{Ctrl}][\sim]$.

\footnotetext{
${ }^{9}$ In the case of the Ramsey model, Solver can handle about 30 years.
} 
Worksheet 5.1

\begin{tabular}{|c|c|c|c|c|c|}
\hline & A & $\mathrm{B}$ & C & D & $E$ \\
\hline 1 & & Initial & Shock & & \\
\hline 2 & $\theta=$ & 0.04 & 0.05 & & \\
\hline 3 & $\beta=$ & $=1 /(1+\$ B \$ 2)$ & $=1 /(1+\$ C \$ 2)$ & & \\
\hline 4 & $y=$ & 1.5 & 1.5 & & \\
\hline 5 & $A=$ & 1 & 1 & & \\
\hline 6 & $\alpha=$ & 0.3 & 0.3 & & \\
\hline 7 & $\delta=$ & 0.05 & 0.05 & & \\
\hline 8 & $n=$ & 0.01 & 0.01 & & \\
\hline 9 & $k^{*}$ & \multirow{2}{*}{\multicolumn{4}{|c|}{$=\left(\left(\$ B \$ 5 * \$ B \$=\left((\$ C \$ 5 * \$ C \$ 6 *(1+\$ C \$ 8)) /\left((1+\$ C \$ 8)^{*}(1\right.\right.\right.\right.$}} \\
\hline 10 & & & & & \\
\hline 11 & Time & $c(t)$ & $k(t)$ & $y(t)$ & $P \vee U(t)$ \\
\hline 12 & 0 & & $=\$ B \$ 9$ & & \\
\hline 13 & 1 & 1.3176 & $=\mathrm{D} 13-\mathrm{B} 13+((1-\$ \mathrm{C} \$ 7) /(1+\$ \mathrm{C} \$ 8))^{*} \mathrm{C} 12$ & $=\$ C \$ 5^{*} \mathrm{C} 12^{\wedge} \$ \mathrm{C} \$ 6$ & $=\left(\$ C \$ 3^{\wedge} \mathrm{A} 12\right)^{\star}\left(\mathrm{B} 13^{\wedge}(1-\$ \mathrm{C} \$ 4)-1\right) /(1-\$ C \$ 4)$ \\
\hline 14 & 2 & 1.3176 & $=\mathrm{D} 14-\mathrm{B} 14+((1-\$ C \$ 7) /(1+\$ C \$ 8))^{*} \mathrm{C} 13$ & $=\$ C \$ 5^{*} \mathrm{C} 13^{\wedge} \$ C \$ 6$ & $=\left(\$ C \$ 3^{n} \mathrm{~A} 13\right)^{*}\left(\mathrm{~B} 14^{n}(1-\$ C \$ 4)-1\right) /(1-\$ C \$ 4)$ \\
\hline 15 & 3 & 1.3176 & $=\mathrm{D} 15-\mathrm{B} 15+((1-\$ \mathrm{C} \$ 7) /(1+\$ \mathrm{C} \$ 8))^{*} \mathrm{C} 14$ & $=\$ C \$ 5^{*} \mathrm{C} 14^{\wedge} \$ \mathrm{C} \$ 6$ & $=\left(\$ C \$ 3^{n} \mathrm{~A} 14\right)^{*}\left(\mathrm{~B} 15^{n}(1-\$ C \$ 4)-1\right) /(1-\$ C \$ 4)$ \\
\hline 16 & 4 & 1.3176 & $=\mathrm{D} 16-\mathrm{B} 16+((1-\$ \mathrm{C} \$ 7) /(1+\$ \mathrm{C} \$ 8))^{*} \mathrm{C} 15$ & $=\$ C \$ 5^{*} \mathrm{C} 15^{\wedge} \$ \mathrm{C} \$ 6$ & $=\left(\$ C \$ 3^{\wedge} \mathrm{A} 15\right)^{*}\left(\mathrm{~B} 16^{\wedge}(1-\$ \mathrm{C} \$ 4)-1\right) /(1-\$ C \$ 4)$ \\
\hline 17 & 5 & 1.3176 & $=\mathrm{D} 17-\mathrm{B} 17+((1-\$ C \$ 7) /(1+\$ C \$ 8))^{*} \mathrm{C} 16$ & $=\$ C \$ 5^{*} \mathrm{C} 16^{\wedge} \$ C \$ 6$ & $=\left(\$ C \$ 3^{n} A 16\right)^{*}\left(B 17^{n}(1-\$ C \$ 4)-1\right) /(1-\$ C \$ 4)$ \\
\hline 18 & 6 & 1.3176 & $=\mathrm{D} 18-\mathrm{B} 18+((1-\$ \mathrm{C} \$ 7) /(1+\$ \mathrm{C} \$ 8))^{*} \mathrm{C} 17$ & $=\$ C \$ 5^{*} \mathrm{C} 17^{\wedge} \$ \mathrm{C} \$ 6$ & $=\left(\$ C \$ 3^{n} \mathrm{~A} 17\right)^{*}\left(\mathrm{~B} 18^{n}(1-\$ C \$ 4)-1\right) /(1-\$ C \$ 4)$ \\
\hline 19 & 7 & 1.3176 & $=\mathrm{D} 19-\mathrm{B} 19+((1-\$ \mathrm{C} \$ 7) /(1+\$ \mathrm{C} \$ 8))^{*} \mathrm{C} 18$ & $=\$ C \$ 5^{*} \mathrm{C} 18^{\wedge} \$ C \$ 6$ & $=\left(\$ C \$ 3^{\wedge} \mathrm{A} 18\right)^{*}\left(\mathrm{~B} 19^{\wedge}(1-\$ C \$ 4)-1\right) /(1-\$ C \$ 4)$ \\
\hline 20 & 8 & 1.3176 & $=\mathrm{D} 20-\mathrm{B} 20+((1-\$ \mathrm{C} \$ 7) /(1+\$ \mathrm{C} \$ 8))^{*} \mathrm{C} 19$ & $=\$ C \$ 5^{*} \mathrm{C} 19^{\wedge} \$ \mathrm{C} \$ 6$ & $=\left(\$ C \$ 3^{n A} 19\right)^{*}\left(\mathrm{~B} 20^{n}(1-\$ C \$ 4)-1\right) /(1-\$ C \$ 4)$ \\
\hline 21 & 9 & 1.3176 & $=\mathrm{D} 21-\mathrm{B} 21+((1-\$ C \$ 7) /(1+\$ C \$ 8))^{*} \mathrm{C} 20$ & $=\$ C \$ 5^{*} \mathrm{C} 20^{\wedge} \$ \mathrm{C} \$ 6$ & $=\left(\$ C \$ 3^{n A 20}\right)^{*}\left(\mathrm{~B} 21^{\wedge}(1-\$ C \$ 4)-1\right) /(1-\$ C \$ 4)$ \\
\hline 22 & 10 & 1.3176 & $=\mathrm{D} 22-\mathrm{B} 22+((1-\$ C \$ 7) /(1+\$ C \$ 8))^{*} \mathrm{C} 21$ & $=\$ C \$ 5^{*} \mathrm{C} 21 \wedge \$ C \$ 6$ & $=\left(\$ C \$ 3^{n} \mathrm{~A} 21\right)^{*}\left(\mathrm{~B} 22^{n}(1-\$ C \$ 4)-1\right) /(1-\$ C \$ 4)$ \\
\hline 23 & 11 & 1.3176 & $=\mathrm{D} 23-\mathrm{B} 23+((1-\$ \mathrm{C} \$ 7) /(1+\$ \mathrm{C} \$ 8))^{*} \mathrm{C} 22$ & $=\$ C \$ 5^{*} \mathrm{C} 22^{\wedge} \$ \mathrm{C} \$ 6$ & $=\left(\$ C \$ 3^{\wedge} \mathrm{A} 22\right)^{*}\left(\mathrm{~B} 23^{\wedge}(1-\$ \mathrm{C} \$ 4)-1\right) /(1-\$ C \$ 4)$ \\
\hline 24 & 12 & 1.3176 & $=\mathrm{D} 24-\mathrm{B} 24+((1-\$ C \$ 7) /(1+\$ C \$ 8))^{*} \mathrm{C} 23$ & $=\$ C \$ 5^{*} \mathrm{C} 23^{\wedge} \$ C \$ 6$ & $=\left(\$ C \$ 3^{n} \mathrm{~A} 23\right)^{*}\left(\mathrm{~B} 24^{n}(1-\$ C \$ 4)-1\right) /(1-\$ C \$ 4)$ \\
\hline 25 & 13 & 1.3176 & $=\mathrm{D} 25-\mathrm{B} 25+((1-\$ \mathrm{C} \$ 7) /(1+\$ \mathrm{C} \$ 8))^{*} \mathrm{C} 24$ & $=\$ C \$ 5^{*} \mathrm{C} 24^{\wedge} \$ \mathrm{C} \$ 6$ & $=\left(\$ C \$ 3^{n} \mathrm{~A} 24\right)^{\star}\left(\mathrm{B} 25^{n}(1-\$ C \$ 4)-1\right) /(1-\$ C \$ 4)$ \\
\hline 26 & 14 & 1.3176 & $=\mathrm{D} 26-\mathrm{B} 26+((1-\$ C \$ 7) /(1+\$ C \$ 8))^{*} \mathrm{C} 25$ & $=\$ C \$ 5^{*} \mathrm{C} 25^{\wedge} \$ \mathrm{C} \$ 6$ & $=\left(\$ C \$ 3^{n} A 25\right)^{*}\left(B 26^{n}(1-\$ C \$ 4)-1\right) /(1-\$ C \$ 4)$ \\
\hline 27 & 15 & 1.3176 & $=\mathrm{D} 27-\mathrm{B} 27+((1-\$ \mathrm{C} \$ 7) /(1+\$ \mathrm{C} \$ 8))^{*} \mathrm{C} 26$ & $=\$ C \$ 5^{*} \mathrm{C} 26^{\wedge} \$ C \$ 6$ & $=\left(\$ C \$ 3^{n} \mathrm{~A} 26\right)^{*}\left(\mathrm{~B} 27^{n}(1-\$ C \$ 4)-1\right) /(1-\$ C \$ 4)$ \\
\hline 28 & 16 & 1.3176 & $=\mathrm{D} 28-\mathrm{B} 28+((1-\$ C \$ 7) /(1+\$ C \$ 8))^{*} \mathrm{C} 27$ & $=\$ C \$ 5^{*} \mathrm{C} 27^{\wedge} \$ C \$ 6$ & $=\left(\$ C \$ 3^{n} \mathrm{~A} 27\right)^{*}\left(\mathrm{~B} 28^{n}(1-\$ C \$ 4)-1\right) /(1-\$ C \$ 4)$ \\
\hline 29 & 17 & 1.3176 & $=\mathrm{D} 29-\mathrm{B} 29+((1-\$ C \$ 7) /(1+\$ \mathrm{C} \$ 8))^{*} \mathrm{C} 28$ & $=\$ C \$ 5^{*} \mathrm{C} 28^{\wedge} \$ C \$ 6$ & $=\left(\$ C \$ 3^{n} \mathrm{~A} 28\right)^{*}\left(\mathrm{~B} 29^{n}(1-\$ C \$ 4)-1\right) /(1-\$ C \$ 4)$ \\
\hline 30 & 18 & 1.3176 & $=\mathrm{D} 30-\mathrm{B} 30+((1-\$ \mathrm{C} \$ 7) /(1+\$ \mathrm{C} \$ 8))^{*} \mathrm{C} 29$ & $=\$ C \$ 5^{*} \mathrm{C} 29^{\wedge} \$ \mathrm{C} \$ 6$ & $=\left(\$ C \$ 3^{n} \mathrm{~A} 29\right)^{*}\left(\mathrm{~B} 30^{\wedge}(1-\$ C \$ 4)-1\right) /(1-\$ C \$ 4)$ \\
\hline 31 & 19 & 1.3176 & $=\mathrm{D} 31-\mathrm{B} 31+((1-\$ \mathrm{C} \$ 7) /(1+\$ \mathrm{C} \$ 8))^{*} \mathrm{C} 30$ & $=\$ C \$ 5^{*} \mathrm{C} 30^{\wedge} \$ \mathrm{C} \$ 6$ & $=\left(\$ C \$ 3^{n} \mathrm{~A} 30\right)^{*}\left(\mathrm{~B} 31^{\wedge}(1-\$ C \$ 4)-1\right) /(1-\$ C \$ 4)$ \\
\hline 32 & 20 & 1.3176 & $=\mathrm{D} 32-\mathrm{B} 32+((1-\$ \mathrm{C} \$ 7) /(1+\$ \mathrm{C} \$ 8))^{*} \mathrm{C} 31$ & $=\$ C \$ 5^{*} \mathrm{C} 31 \wedge \$ C \$ 6$ & $=\left(\$ C \$ 3^{n} A 31\right)^{*}\left(B 32^{n}(1-\$ C \$ 4)-1\right) /(1-\$ C \$ 4)$ \\
\hline 33 & & & & & \\
\hline 34 & & & & PVLTU & $=S U M(\$ E \$ 13: \$ E \$ 32)$ \\
\hline
\end{tabular}

Rows 2 to 8 include realistic parameter values, which are drawn from the real business cycle literature. ${ }^{10}$ The rate of time preference, $\theta$, is four percent per year; the curvature parameter of the annual utility function, $\gamma$, is 1.5 ; the technological parameters of the Cobb-Douglas production function are $A=1$ and $\alpha=0.3$; the depreciation rate, $\delta$, is five percent per year; and the rate of population growth, $n$, is one percent per year. Column B includes the parameter values before an economic shock, and column $\mathrm{C}$ is used to input new values that reflect economic shocks. The first shock is an increase in the rate of time preference from four percent to five percent per year. This reduces the subjective discount factor, $\beta$, from 0.96 in cell B3 to 0.95 in cell C3. Cells B9 and C9 compute the steady state amount of capital per worker before and after

\footnotetext{
${ }^{10}$ See Cooley (1995) and Walsh (2003).
} 
the shock, using equation (12). ${ }^{11}$ The increase in time preference reduces the steady state amount of capital from 4.85 units to 4.23 units. The capital stock falls because the representative consumer discounts utility from future consumption more strongly, therefore the consumer is less inclined to defer consumption and save.

Worksheet 5.2

\begin{tabular}{|c|c|c|c|c|c|}
\hline & A & $B$ & C & D & $E$ \\
\hline 1 & & Initial & Shock & & \\
\hline 2 & $\theta=$ & 0.04 & 0.05 & & \\
\hline 3 & $\beta=$ & 0.9615 & 0.9524 & & \\
\hline 4 & $y=$ & 1.5 & 1.5 & & \\
\hline 5 & $A=$ & 1 & 1 & & \\
\hline 6 & $\alpha=$ & 0.3 & 0.3 & & \\
\hline 7 & $\delta=$ & 0.05 & 0.05 & & \\
\hline 8 & $n=$ & 0.01 & 0.01 & & \\
\hline 9 & $k^{*}$ & 4.8451 & 4.2250 & & \\
\hline \multicolumn{6}{|l|}{10} \\
\hline 11 & Time & $c(t)$ & $k(t)$ & $y(t)$ & $P V U(t)$ \\
\hline 12 & 0 & & 4.8451 & & \\
\hline 13 & 1 & 1.3176 & 4.8451 & 1.6054 & 0.2576 \\
\hline 14 & 2 & 1.3176 & 4.8450 & 1.6054 & 0.2454 \\
\hline 15 & 3 & 1.3176 & 4.8450 & 1.6054 & 0.2337 \\
\hline 16 & 4 & 1.3176 & 4.8450 & 1.6054 & 0.2226 \\
\hline 17 & 5 & 1.3176 & 4.8450 & 1.6054 & 0.2120 \\
\hline 18 & 6 & 1.3176 & 4.8450 & 1.6054 & 0.2019 \\
\hline 19 & 7 & 1.3176 & 4.8450 & 1.6054 & 0.1923 \\
\hline 20 & 8 & 1.3176 & 4.8450 & 1.6054 & 0.1831 \\
\hline 21 & 9 & 1.3176 & 4.8450 & 1.6054 & 0.1744 \\
\hline 22 & 10 & 1.3176 & 4.8450 & 1.6054 & 0.1661 \\
\hline 23 & 11 & 1.3176 & 4.8450 & 1.6054 & 0.1582 \\
\hline 24 & 12 & 1.3176 & 4.8450 & 1.6054 & 0.1506 \\
\hline 25 & 13 & 1.3176 & 4.8450 & 1.6054 & 0.1435 \\
\hline 26 & 14 & 1.3176 & 4.8450 & 1.6054 & 0.1366 \\
\hline 27 & 15 & 1.3176 & 4.8450 & 1.6054 & 0.1301 \\
\hline 28 & 16 & 1.3176 & 4.8450 & 1.6054 & 0.1239 \\
\hline 29 & 17 & 1.3176 & 4.8450 & 1.6054 & 0.1180 \\
\hline 30 & 18 & 1.3176 & 4.8450 & 1.6054 & 0.1124 \\
\hline 31 & 19 & 1.3176 & 4.8450 & 1.6054 & 0.1071 \\
\hline 32 & 20 & 1.3176 & 4.8450 & 1.6054 & 0.1020 \\
\hline \multicolumn{6}{|l|}{33} \\
\hline 34 & & & & PVLTU & 3.3713 \\
\hline
\end{tabular}

Below row 11, the worksheet shows how the economy passes through the transition period from the initial steady state to the new one in response to the increase in time preference. Referencing cell B9, cell C12 includes the capital per worker in the initial steady state, which is 4.85 units. This is the initial condition of the optimal control problem. The formula in cell $\mathrm{C} 13$ is

11 The full formulas in cells B9 and C9 are:

Cell B9: $=((\$ B \$ 5 * \$ B \$ 6 *(1+\$ B \$ 8)) /((1+\$ B \$ 8) *(1+\$ B \$ 2)-(1-\$ B \$ 7)))^{\wedge}(1 /(1-\$ B \$ 6))$

Cell C9: $=((\$ C \$ 5 * \$ C \$ 6 *(1+\$ C \$ 8)) /((1+\$ C \$ 8) *(1+\$ C \$ 2)-(1-\$ C \$ 7)))^{\wedge}(1 /(1-\$ C \$ 6))$ 
the constraint (11), which captures the mechanics of capital accumulation. Cell D13 includes the production function (10), and cell E13 is the discounted value of annual utility, using the CRRA utility function. The present value of lifetime utility in cell E34 is a functional, $V\left(k_{0}, \vec{c}\right)$, whose value depends on the initial capital stock, $k_{0}$, in cell B9 and on the time path of consumption, $\vec{c}$, in cells B13 to B32.

It is natural to initiate the Solver tool with the original steady state consumption, but some arbitrary time path of consumption will also work, provided it is not too far away from the optimal solution after the shock. Using equations (12) and (13), consumption is 1.3176 units in the original steady state. Write this into cell B13 and copy it downward. Since the rate of time preference has risen to five percent, the original steady state consumption is no longer optimal. The representative consumer chooses the best time path of consumption, which maximizes the present value of lifetime utility in cell E34. Designate cell E34 as the target cell and start Solver from the Tools menu. Write the range of cells with the time path of consumption, $\$ B \$ 13: \$ B \$ 32$, into dialog box 2. The first constraint, $\$ \mathrm{~B} \$ 13: \$ \mathrm{~B} \$ 32>=0$, requires that consumption is nonnegative in each year. The second constraint, $\$ C \$ 32>=\$ C \$ 9$, guarantees that the optimal time path of capital per worker approaches the new steady state value after the shock. Without this constraint, the consumer would consume the entire capital stock because goods do not yield utility after time $T$.

Dialog Box 2

\begin{tabular}{|c|c|c|}
\hline \multicolumn{2}{|l|}{ Solver Parameters } & 2 \\
\hline \multicolumn{2}{|l|}{ Set Target Cell: $\quad$ TSE\$34 } & Solve \\
\hline \multicolumn{2}{|c|}{$\begin{array}{l}\text { Equal To: } \odot \text { Max } \backsim \text { Min } \backsim \text { value of: } \quad 10 \\
\text { By Changing Cells: }\end{array}$} & Close \\
\hline$\$ B \$ 13: \$ B \$ 32$ & Guess & \\
\hline \multicolumn{2}{|l|}{ Subject to the Constraints: } & Options \\
\hline \multirow{4}{*}{$\begin{array}{l}\$ B \$ 13: \$ B \$ 32>=0 \\
\$ C \$ 32>=\$ C \$ 9\end{array}$} & Add & \\
\hline & Change & \\
\hline & Delete & Reset All \\
\hline & & Help \\
\hline
\end{tabular}


After an increase in the rate of time preference, the economy passes through a transition period until it reaches the new steady state at a lower capital stock. Worksheet 6 shows the time paths of capital, output and consumption per worker. The adjustment paths are first steep and then flat, with most of the adjustment occurring within 15 years. It is worthwhile for the consumer to modify consumption after the change in the rate of time preference. Optimal behavior increases lifetime utility from 3.37 units with no change in consumption (worksheet 5.2) to 3.55 units with optimal consumption (worksheet 6).

Worksheet 6

\begin{tabular}{|c|c|c|c|c|c|}
\hline & $\mathrm{A}$ & $B$ & $\mathrm{C}$ & D & $E$ \\
\hline 1 & & Initial & Shock & & \\
\hline 2 & $\theta=$ & 0.04 & 0.05 & & \\
\hline 3 & $\beta=$ & 0.9615 & 0.9524 & & \\
\hline 4 & $y=$ & 1.5 & 1.5 & & \\
\hline 5 & $A=$ & 1 & 1 & & \\
\hline 6 & $\alpha=$ & 0.3 & 0.3 & & \\
\hline 7 & $\delta=$ & 0.05 & 0.05 & & \\
\hline 8 & $n=$ & 0.01 & 0.01 & & \\
\hline 9 & $k^{*}$ & 4.8451 & 4.2250 & & \\
\hline \multicolumn{6}{|l|}{10} \\
\hline 11 & Time & $c(t)$ & $k(t)$ & $y(t)$ & $P \vee U(t)$ \\
\hline 12 & 0 & & 4.8451 & & \\
\hline 13 & 1 & 1.3770 & 4.7856 & 1.6054 & 0.2956 \\
\hline 14 & 2 & 1.3697 & 4.7312 & 1.5995 & 0.2772 \\
\hline 15 & 3 & 1.3626 & 4.6816 & 1.5940 & 0.2600 \\
\hline 16 & 4 & 1.3561 & 4.6364 & 1.5890 & 0.2441 \\
\hline 17 & 5 & 1.3502 & 4.5951 & 1.5844 & 0.2294 \\
\hline 18 & 6 & 1.3448 & 4.5574 & 1.5801 & 0.2157 \\
\hline 19 & 7 & 1.3399 & 4.5230 & 1.5762 & 0.2031 \\
\hline 20 & 8 & 1.3355 & 4.4915 & 1.5726 & 0.1914 \\
\hline 21 & 9 & 1.3315 & 4.4625 & 1.5693 & 0.1806 \\
\hline 22 & 10 & 1.3279 & 4.4358 & 1.5663 & 0.1704 \\
\hline 23 & 11 & 1.3247 & 4.4110 & 1.5635 & 0.1611 \\
\hline 24 & 12 & 1.3219 & 4.3879 & 1.5608 & 0.1523 \\
\hline 25 & 13 & 1.3195 & 4.3661 & 1.5584 & 0.1442 \\
\hline 26 & 14 & 1.3174 & 4.3454 & 1.5561 & 0.1366 \\
\hline 27 & 15 & 1.3157 & 4.3254 & 1.5538 & 0.1295 \\
\hline 28 & 16 & 1.3143 & 4.3058 & 1.5517 & 0.1229 \\
\hline 29 & 17 & 1.3133 & 4.2863 & 1.5496 & 0.1167 \\
\hline 30 & 18 & 1.3126 & 4.2666 & 1.5475 & 0.1110 \\
\hline 31 & 19 & 1.3122 & 4.2463 & 1.5453 & 0.1056 \\
\hline 32 & 20 & 1.3121 & 4.2250 & 1.5431 & 0.1005 \\
\hline 33 & & & & & \\
\hline 34 & & & & PVLTU & 3.5478 \\
\hline
\end{tabular}

Similar simulations can be conducted for changes in the other structural parameters of the economy: the technological coefficients of the Cobb-Douglas production function, $A$ and $\alpha$, the depreciation rate, $\delta$, and the rate of population growth, $n$. Changes to these parameters produce a 
new steady state, which the economy approaches after some transition period. A change in the curvature parameter of the annual utility function, $\gamma$, does not yield a new steady state, but it affects the time path of the economy towards the steady state if one of the other parameters changes. Technological shocks, which play a major role in modern business cycle research, can be modeled either by an autonomous shift in the parameter $A$ or by adding a constant $z$ to the production function, $y_{t}=A k_{t-1}^{\alpha}+z$. Unlike a shift in $A$, the inclusion of $z$ in the production function does not affect the marginal products of capital and labor. The coefficient $\alpha$, which measures the income share of capital in a competitive economy, is also a technological parameter, but it is rarely used to model technological change because it is generally perceived as being stable.

The optimal response of the representative consumer to a technological shock depends on how long it is expected to last. First, suppose that the production function shifts upward for just one year. Return to worksheet 5 and change the rate of time preference to four percent in cell $\mathrm{C} 2$ to keep it constant. Then, add 0.2 to the production function in cell D13: $=\$ C \$ 5^{*} \mathrm{C} 12^{\wedge} \$ \mathrm{C} \$ 6+0.2$. This amounts to a parallel upward shift of the production function by 0.2 units in year 1 . Before the technological shock steady state consumption was 1.3176 , which serves as the initial guess for the time path of consumption. After the technological shock, the initial steady state consumption is no longer optimal. Use Solver to maximize the lifetime utility of the consumer in cell E34. The dialog box should look like the previous dialog box 2.

Worksheet 7 shows the response of the economy to the temporary upward shift in the production function. In year 1, output increases from 1.6054 commodity units (worksheet 5.2) to 1.8054 units (worksheet 7). The extra 0.2 units of output are mostly saved and added to the capital stock. The amount of capital per worker advances by 0.175 units, and consumption grows by 0.025 units. Thus, the marginal propensity to consume out of the temporary increase in output 
is only 12.5 percent. The new physical capital adds to output in the following years, allowing the consumer to maintain a slightly higher consumption path. Only a small amount of the extra output is consumed in year 1 because the curvature of the annual utility function implies that an increase in consumption reduces marginal utility. Therefore, the consumer smoothens the time path of consumption. By year 20, the additional capital has been used up, and the capital has fallen back to the steady state level, which has not changed.

Worksheet 7

\begin{tabular}{|c|c|c|c|c|c|}
\hline & A & $\mathrm{B}$ & C & D & $E$ \\
\hline 1 & & Initial & Shock & & \\
\hline 2 & $\theta=$ & 0.04 & 0.04 & & \\
\hline 3 & $\beta=$ & 0.9615 & 0.9615 & & \\
\hline 4 & $y=$ & 1.5 & 1.5 & & \\
\hline 5 & $A=$ & 1 & 1 & & \\
\hline 6 & $\alpha=$ & 0.3 & 0.3 & & \\
\hline 7 & $\delta=$ & 0.05 & 0.05 & & \\
\hline 8 & $n=$ & 0.01 & 0.01 & & \\
\hline 9 & $k^{*}$ & 4.8451 & 4.8451 & & \\
\hline \multicolumn{6}{|l|}{10} \\
\hline 11 & Time & $c(t)$ & $k(t)$ & $y(t)$ & $P \vee U(t)$ \\
\hline 12 & 0 & & 4.8451 & & \\
\hline 13 & 1 & 1.3428 & 5.0198 & 1.8054 & 0.2741 \\
\hline 14 & 2 & 1.3400 & 5.0042 & 1.6226 & 0.2618 \\
\hline 15 & 3 & 1.3383 & 4.9896 & 1.6211 & 0.2507 \\
\hline 16 & 4 & 1.3367 & 4.9762 & 1.6196 & 0.2401 \\
\hline 17 & 5 & 1.3352 & 4.9637 & 1.6183 & 0.2301 \\
\hline 18 & 6 & 1.3338 & 4.9521 & 1.6171 & 0.2205 \\
\hline 19 & 7 & 1.3326 & 4.9413 & 1.6160 & 0.2114 \\
\hline 20 & 8 & 1.3314 & 4.9314 & 1.6149 & 0.2026 \\
\hline 21 & 9 & 1.3302 & 4.9221 & 1.6139 & 0.1943 \\
\hline 22 & 10 & 1.3292 & 4.9136 & 1.6130 & 0.1864 \\
\hline 23 & 11 & 1.3283 & 4.9056 & 1.6122 & 0.1788 \\
\hline 24 & 12 & 1.3274 & 4.8982 & 1.6114 & 0.1715 \\
\hline 25 & 13 & 1.3267 & 4.8912 & 1.6107 & 0.1646 \\
\hline 26 & 14 & 1.3260 & 4.8846 & 1.6100 & 0.1581 \\
\hline 27 & 15 & 1.3255 & 4.8783 & 1.6093 & 0.1518 \\
\hline 28 & 16 & 1.3251 & 4.8721 & 1.6087 & 0.1458 \\
\hline 29 & 17 & 1.3249 & 4.8658 & 1.6081 & 0.1401 \\
\hline 30 & 18 & 1.3249 & 4.8594 & 1.6075 & 0.1347 \\
\hline 31 & 19 & 1.3250 & 4.8525 & 1.6068 & 0.1296 \\
\hline 32 & 20 & 1.3254 & 4.8451 & 1.6062 & 0.1247 \\
\hline 33 & & & & & \\
\hline 34 & & & & PVLTU & 3.7718 \\
\hline
\end{tabular}

To model a permanent parallel upward shift in the production function, copy cell D13 downward to cell D32. This adds the shift parameter, $z=0.2$, to output in each year. Then, reset the time path of consumption to the steady state level of 1.3176 , and use Solver to maximize the value of lifetime utility in cell E34. Worksheet 8 shows the response of the economy to the 
permanent upward shift in the production function. The marginal propensity to consume out of a permanent increase in income equals 1 because both output and consumption increase by 0.2 in year 1. Indeed, output and consumption increase by 0.2 in every year. Since output increases permanently, there is no need to save and the capital stock remains constant. Thus, the marginal propensity to consume out of permanent income is 1 , whereas the marginal propensity to consume out of temporary income is small. This finding accords with Milton Friedman's permanent income hypothesis and Franco Modigliani’s life-cycle hypothesis of consumption.

Worksheet 8

\begin{tabular}{|c|c|c|c|c|c|}
\hline & A & $B$ & $\mathrm{C}$ & D & $E$ \\
\hline 1 & & Initial & Shock & & \\
\hline 2 & $\theta=$ & 0.04 & 0.04 & & \\
\hline 3 & $\beta=$ & 0.9615 & 0.9615 & & \\
\hline 4 & $y=$ & 1.5 & 1.5 & & \\
\hline 5 & $A=$ & 1 & 1 & & \\
\hline 6 & $\alpha=$ & 0.3 & 0.3 & & \\
\hline 7 & $\delta=$ & 0.05 & 0.05 & & \\
\hline 8 & $n=$ & 0.01 & 0.01 & & \\
\hline 9 & $k^{*}$ & 4.8451 & 4.8451 & & \\
\hline \multicolumn{6}{|c|}{10} \\
\hline 11 & Time & $c(t)$ & $k(t)$ & $y(t)$ & $P V U(t)$ \\
\hline 12 & 0 & & 4.8451 & & \\
\hline 13 & 1 & 1.5182 & 4.8445 & 1.8054 & 0.3768 \\
\hline 14 & 2 & 1.5174 & 4.8446 & 1.8054 & 0.3619 \\
\hline 15 & 3 & 1.5175 & 4.8447 & 1.8054 & 0.3481 \\
\hline 16 & 4 & 1.5176 & 4.8446 & 1.8054 & 0.3347 \\
\hline 17 & 5 & 1.5176 & 4.8446 & 1.8054 & 0.3218 \\
\hline 18 & 6 & 1.5176 & 4.8446 & 1.8054 & 0.3094 \\
\hline 19 & 7 & 1.5175 & 4.8447 & 1.8054 & 0.2975 \\
\hline 20 & 8 & 1.5175 & 4.8448 & 1.8054 & 0.2861 \\
\hline 21 & 9 & 1.5174 & 4.8449 & 1.8054 & 0.2750 \\
\hline 22 & 10 & 1.5174 & 4.8451 & 1.8054 & 0.2645 \\
\hline 23 & 11 & 1.5174 & 4.8453 & 1.8054 & 0.2543 \\
\hline 24 & 12 & 1.5175 & 4.8454 & 1.8054 & 0.2445 \\
\hline 25 & 13 & 1.5176 & 4.8454 & 1.8055 & 0.2351 \\
\hline 26 & 14 & 1.5177 & 4.8454 & 1.8055 & 0.2261 \\
\hline 27 & 15 & 1.5177 & 4.8453 & 1.8055 & 0.2175 \\
\hline 28 & 16 & 1.5178 & 4.8451 & 1.8054 & 0.2091 \\
\hline 29 & 17 & 1.5178 & 4.8448 & 1.8054 & 0.2011 \\
\hline 30 & 18 & 1.5178 & 4.8447 & 1.8054 & 0.1933 \\
\hline 31 & 19 & 1.5176 & 4.8447 & 1.8054 & 0.1858 \\
\hline 32 & 20 & 1.5172 & 4.8451 & 1.8054 & 0.1786 \\
\hline \multicolumn{6}{|l|}{33} \\
\hline 34 & & & & PVLTU & 5.3215 \\
\hline
\end{tabular}




\section{Analytical Solution}

In an optimal control problem the aim is to find the optimal time path of the decision variable, which maximizes a value functional. This problem is much more difficult than finding the maximum of a function in standard calculus because the solution consists of an entire function, the time path of the decision variable. In a complicated mathematical problem it is often useful to start by guessing the solution. Indeed, mathematicians often proceed in the same way as desperate students, who guess the solution of an equation and then check its validity. How successful a guess is depends on intuition, experience and luck. In an optimal control problem it is naturally not realistic to guess the exact form of the optimal time path of the decision variable. Still, for analytical purposes we may postulate that the optimal time path of the decision variable, $\vec{u}$, is known. Then, the functional, $V\left(x_{0}, \vec{u}\right)$, attains a maximum for a given initial value of the state variable, $x_{0}$.

$$
V^{*}\left(x_{0}\right)=\max _{\vec{u}} V\left(x_{0}, \vec{u}\right)
$$

$V^{*}\left(x_{0}\right)$, which is called the optimal value function, is the maximum value of the value functional, $V\left(x_{0}, \vec{u}\right)$, if the decision maker chooses the best time path, $\vec{u}$, of the decision variable. ${ }^{12}$ Once it is assumed that the decision maker behaves optimally, the value of a project depends only on the starting value of the state variable, $x_{0}$. For this reason, the time path of the decision variable is not an argument in the optimal value function, $V^{*}\left(x_{0}\right)$. In the jargon of the optimal control literature, the time path of the decision variable has been 'maximized out'. The assumption that the decision maker behaves optimally transforms the functional, $V\left(x_{0}, \vec{u}\right)$, into

\footnotetext{
${ }^{12}$ The optimal value function is analogous to the indirect utility function in static microeconomic analysis.
} 
the function, $V^{*}\left(x_{0}\right)$. This is an important mathematical simplification because standard calculus can be applied to the optimal value function, $V^{*}\left(x_{0}\right)$, which is a function and not a functional.

The valuation of a firm requires an assumption on the behavior of the decision maker who controls it. In financial economics it is usually assumed that the decision maker will adopt the optimal time path of the decision variable that maximizes the present value of the stream of income generated by an asset. But other behavioral assumptions may be more realistic. In the wake of the Enron scandal, American share prices fell because the public had lost the belief that corporate managers maximize the value of firms on behalf of share holders. Different assumptions on the behavior of decisions makers produce different asset values. An important strand of financial literature considers the conflict of interest between managers and share holders, which affects corporate governance and hence the value of firms.

The optimal value function shows the relationship between the value of a firm and its physical capital stock. Differentiating the optimal value function yields the value of a single capital unit, the so-called shadow price of capital.

$$
\lambda_{0}=\frac{d V^{*}\left(x_{0}\right)}{d x_{0}}
$$

The shadow price of capital, $\lambda_{0}$, measures the effect of an extra capital unit on the value of a firm. For example, the shadow price of a fish is $\$ 10$ if adding an extra fish to a fish stock increases the fishery's value by $\$ 10$. Similarly, extracting one unit of ore reduces the value of a mine by the ore's shadow price. An extra capital unit adds value to an enterprise because it contributes to current and future revenues. Since the shadow price of capital is the first derivative of the optimal value function, $V^{*}\left(x_{0}\right)$, it is assumed that the decision maker behaves optimally after the extra 
capital unit is added or used up. The shadow price of capital is indeterminate if the behavior of the decision maker is unknown.

John Maynard Keynes introduced the notion of 'user cost' in the theory of the firm. He defined user cost as "the reduction in the value of the [capital] equipment due to using it as compared with not using it". Keynes argued that firms add the marginal user cost of capital to marginal factor cost when deciding on the optimal production plan.

"User cost constitutes one of the links between the present and the future. For in deciding his scale of production an entrepreneur has to exercise a choice between using up his equipment now and preserving it to be used later on. It is the expected sacrifice of future benefit involved in present use which determines the amount of the user cost, and it is the marginal amount of this sacrifice which, together with the marginal factor cost and the expectation of the marginal proceeds, determines his scale of production." (Keynes 1936, Ch. 6)

A firm's short-run supply curve lies above the marginal factor cost curve because "the shortperiod supply price is the sum of the marginal factor cost and the marginal user cost." Keynes viewed the theory of value as incomplete because it did not pay attention to the user cost of capital in the production process.

"Supply price is, I think, an incompletely defined term, if the problem of defining user cost has been ignored."

"Now in the modern theory of value it has been a usual practice to equate the short-period supply price to the marginal factor cost alone. It is obvious, however, that this is only legitimate if marginal user cost is zero, ..." (Keynes 1936, Ch. 6)

Keynes' contribution to the theory of value, the notion of user cost, is now largely forgotten. Even advanced microeconomic textbooks do not discuss user cost. This may be the case because Keynes did not develop a formal dynamic optimization framework, which would have elucidated the concept of user cost. Despite his extensive mathematical training, Keynes used mathematics sparingly in his writings. But the concept of user cost has become central in resource economics, where in Keynes' view "the necessity of allowing for user cost is obvious." Keynes had however more in mind than applying user cost just to the exploitation of natural 
resources. The next quotation shows that he believed that capital equipment is subject to user cost in any enterprise.

"In the case of raw materials the necessity of allowing for user cost is obvious;-if a ton of copper is used up to-day it cannot be used to-morrow, and the value which the copper would have for the purpose of to-morrow must clearly be reckoned as a part of the marginal cost. But the fact has been overlooked that copper is only an extreme case of what occurs whenever capital equipment is used to produce. The assumption that there is a sharp division between raw materials where we must allow for the disinvestment due to using them and fixed capital where we can safely neglect it does not correspond to the facts;--especially in normal conditions where equipment is falling due for replacement every year and the use of equipment brings nearer the date at which replacement is necessary." (Keynes 1936, Ch. 6)

The following steps derive the optimum conditions for a firm that considers the user cost of physical capital. At any time $t$, the value of a firm equals the shadow price of capital multiplied by the firm's capital stock, $\lambda(t) \times x(t)$. Since the decision on the optimal time path of output is made at time 0 , the shadow price of capital at time $t$ is expressed in present value terms. Thus, $\lambda(t)$ is the marginal value of capital at time $t$, expressed in present value terms at time 0 , and $\lambda(t) \times x(t)$ is the corresponding present value of the firm. At each point in time, the production decision changes the value of the firm by

$$
\frac{d[\lambda(t) \times x(t)]}{d t}=\lambda \dot{x}+\dot{\lambda} x
$$

$\dot{x}$ and $\dot{\lambda}$ are the time derivatives $d x / d t$ and $d \lambda / d t$. The firm's value changes because the amount of physical capital changes, $\lambda \dot{x}$, and the value of this capital changes, $\dot{\lambda} x$. Let $f(x, u)$ be the net revenue at time $t$, expressed in present value terms. The decision maker chooses the time path of output that maximizes the sum of the momentary net revenue and the change in the value of the firm at every instant.

$$
f(x, u)+\lambda \dot{x}+\dot{\lambda} x
$$


The time path of the capital stock must fulfill the constraint $\dot{x}=g(x, u)$. This constraint gives rise to an optimal control problem because the growth rate of the state variable, $\dot{x}$, depends both on the decision variable, $u$, and the state variable, $x .{ }^{13}$ Substituting the dynamic constraint into equation (17) yields:

$$
f(x, u)+\lambda g(x, u)+\dot{\lambda} x
$$

Partial differentiation of expression (18) produces two conditions that the optimal time paths of the decision variable and state variable must fulfill:

$$
\begin{aligned}
& f_{u}+\lambda g_{u}=0 \\
& f_{x}+\lambda g_{x}+\dot{\lambda}=0
\end{aligned}
$$

The subscripts $u$ and $x$ indicate partial derivatives. For example, $f_{u}=\partial f / \partial u$ measures the effect of a small change in the decision variable, $u$, on net revenue. Equation (19) is called the maximum principle, and equation (20), which has many names, is known as the auxiliary, costate, adjoint, influence or multiplier equation. Some authors also call the entire optimization procedure Pontryagin's maximum principle.

Consider the economic interpretation of the maximum principle (19). Since capital is used up in the production process, a small increase in output, $u$, reduces the value of the firm by lowering the growth rate of the capital stock. The marginal user cost of capital, $-\lambda g_{u}$, is the fall in the growth rate of the capital stock, $g_{u}<0$, valued at the shadow price of capital, $\lambda$. The maximum principle says that at each instant along the optimal time path of production, the effect of a small change in output on net revenue, $f_{u}$, must equal the marginal user cost of capital, $-\lambda g_{u}$. It is worthwhile to raise output until the increase in net revenue is counterbalanced by the

\footnotetext{
13 The constraint 4 provides an example.
} 
reduction in the firm's value from using its capital equipment more intensively. This is what Keynes had in mind when he argued that "it is the marginal amount of this sacrifice [the user cost] which, together with the marginal factor cost and the expectation of the marginal proceeds, determines his scale of production." ${ }^{14}$

The maximum principle is often derived from the so-called Hamiltonian, an auxiliary function that is defined as $H=f+\lambda g$. Just set the partial derivative of the Hamiltonian equal to zero, $H_{u}=f_{u}+\lambda g_{u}=0$. The second term in the Hamiltonian, $\lambda g$, is the user cost of capital, and $\lambda g_{u}$ is the marginal user cost. The Hamiltonian has an interesting economic interpretation; it measures the loss that arises when a project is postponed or suspended for an instant. This loss consists of the sum of the momentary net revenue, $f$, and the user cost of capital, $\lambda g$. It should be noted that the user cost of capital can be positive or negative. A fishery whose fish stock is less than the steady state value will chose a time path of fishing that allows for an increase in the fish stock, $\lambda \dot{x}=\lambda g>0$. However, it is the marginal user cost that enters the maximum principle, and, using Keynes' words, "it is difficult to conceive of a case where the marginal user cost associated with an increase in [output, i.e. $-\lambda g_{u}$,] will be other than positive."

As discussed in section 2, the operation of a mine is a special case that leads to a problem in the calculus of variations. Since the decision maker has complete control of the ore reserve, the general constraint, $\dot{x}=g(x, u)$, simplifies to constraint 2, which is $\dot{x}=g(u)=-u$. Therefore, the marginal user cost equals the shadow price of ore, $-\lambda g_{u}=-\lambda(-1)=\lambda$. The maximum principle then implies that along the optimal time path of ore extraction marginal net revenue, $f_{u}$, equals the shadow price of ore, $\lambda$. In the preceding quotation Keynes put it this way, "... if a ton of

\footnotetext{
${ }^{14}$ Keynes was also among the first to grasp the dynamic optimization problem of a forward looking consumer. Ramsey (1928, p. 547) acknowledged Keynes' help in the interpretation of the optimum condition that arises in the analysis of the consumption-saving decision.
} 
copper is used up to-day it cannot be used to-morrow, and the value which the copper would have for the purpose of to-morrow must clearly be reckoned as a part of the marginal cost."

Figure 1. User Cost

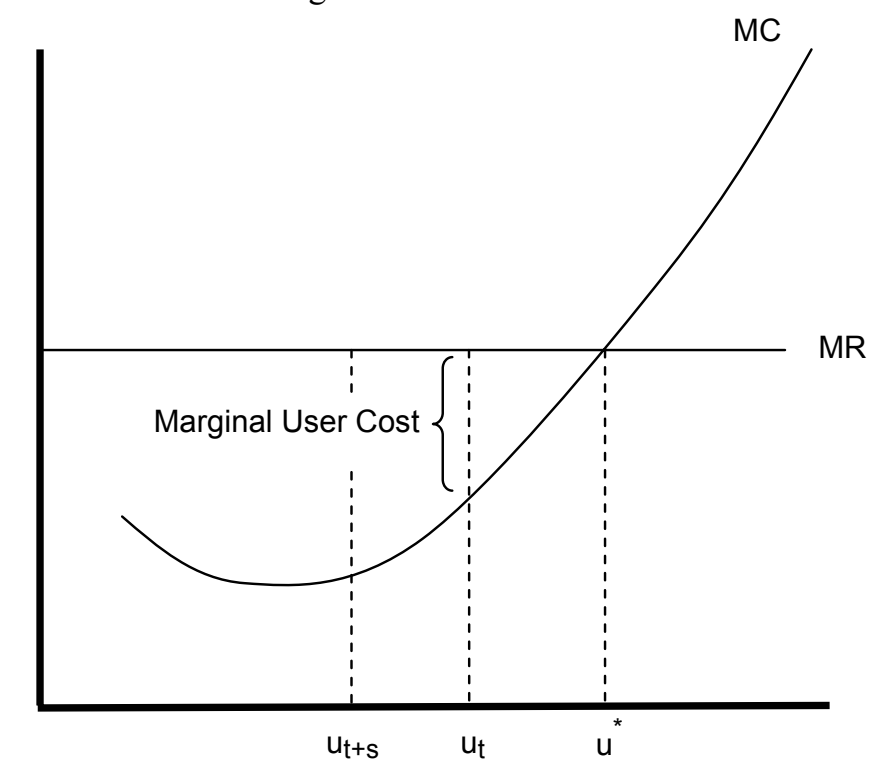

Figure 1 illustrates the maximum principle. The horizontal line shows marginal revenue, $M R$, and the upward sloping line represents marginal factor cost, $M C$. Static optimization produces output $u^{*}$, where marginal net revenue is zero, $f_{u}=M R-M C=0$. The dynamic optimum occurs at the lower output, $u_{t}$, because the decision maker adds the marginal user cost, $-\lambda g_{u}$, to marginal factor cost. For example, the private owner of a natural resource produces $u_{t}$, whereas output is $u^{*}$ in an open access system, as in the case of fish stocks in international waters. Privatization works against overexploitation of natural resources because the owner of a resource cares about the user cost of capital. Without well defined property rights, the decision maker does not take into consideration the effect of the output decision on the asset value of the resource. It should be noted that figure 1, which is borrowed from standard microeconomics, applies to a point in time, whereas dynamic optimization deals with behavior over time. Usually, 
a firm's output changes over time. For example, it may gradually fall from $u_{t}$ to $u_{t+s}$, and it is $u_{t}$ only at an instant in the project's life. Thus, the location of the Keynesian short-run supply curve, which lies above the marginal cost curve, depends on the momentary value of marginal user cost.

The costate equation (20) also has an economic interpretation. At a point in time, an extra capital unit increases net revenue by $f_{x}$, and the growth rate of capital changes by $g_{x}$. The total benefit of an extra capital unit is the sum of the immediate increase in net revenue, $f_{x}$, and the change in the value of the firm, $\lambda g_{x}$. The cost of holding capital is the fall in its shadow price, $\dot{\lambda}<0 .{ }^{15}$ Thus, the costate equation shows that along the optimal time path of capital the firm maintains a sufficient capital stock so that the total marginal benefit of capital, $f_{x}+\lambda g_{x}$, equals its marginal cost, $-\dot{\lambda}$. Dorfman (1969) pointed out that "this finding is reminiscent of the figure of speech of nineteen century capital theorists. They said that a capital good embodied a certain amount of value which it imparted gradually to the commodities that were made with its assistance. That is just what is going on here. Each capital good is gradually decreasing in value $[\dot{\lambda}<0]$ at precisely the same rate at which it is giving rise to valuable outputs, either currently saleable $\left[f_{x}\right]$ or stored for the future in accumulated capital $\left[\lambda g_{x}\right] . "$ It should be noted that the costate equation was derived from the extended Hamiltonian (18), which adds the change in the value of the existing capital, $\dot{\lambda} x$, to the standard Hamiltonian, $H=f+\lambda g .{ }^{16}$

\footnotetext{
${ }^{15}$ It is possible that the shadow price of capital rises along the optimal time path. This is the case when the firm starts with a capital stock that exceeds the steady state value.

${ }^{16}$ As Keynes was unaware of the costate equation, he found it difficult to deal with depreciation. He treated the terms user cost and depreciation interchangeably, although he preferred user cost. He may have sensed that something was missing. In fact, the firm's capital depreciates in the production process if $\lambda g+\dot{\lambda} x$ is negative in the extended Hamiltonian. Keynes focused on the user cost of capital, $\lambda g$, and Dorfman considered a fall in the value of existing capital, $\dot{\lambda} x$. Both Keynes and Dorfman refer to depreciation, but the capital stock may also appreciate.
} 
Converting the costate equation (20) from present values to current values clarifies the nature of the holding cost of capital. Let $\mu(t)$ be the increase in the current value of a firm that acquires a capital unit at time $t$. Then, $\lambda(t)$ is the corresponding present value:

$$
\lambda(t)=\mu(t) e^{-r t}
$$

Differentiating equation (21) yields $\dot{\lambda}=\dot{\mu} e^{-r t}+\mu e^{-r t}(-r)$. Next, substitute equation (21) and its first derivative into the costate equation (20).

$$
f_{x}+\mu e^{-r t} g_{x}+\dot{\mu} e^{-r t}+\mu e^{-r t}(-r)=0
$$

Finally, multiply by $e^{r t}$, substitute $F_{x}=f_{x} e^{r t}$, and rearrange.

$$
F_{x}+\mu g_{x}=r \mu-\dot{\mu}
$$

The transformed costate equation, which uses current values, holds at any time point $t{ }^{17}$ The right-hand side shows the marginal holding cost of capital, which equals the opportunity cost of a capital unit, $r \mu$, adjusted for a possible capital gain or loss, $\dot{\mu}$. Thus, along the optimal time path of capital, the total marginal benefit of capital, $F_{x}+\mu g_{x}$, equals the marginal holding cost of capital. In the steady state, the current value of the shadow price of capital is constant, $\dot{\mu}=0$. Therefore, the total marginal benefit of capital, $F_{x}+\mu g_{x}$, equals the opportunity cost of capital, $r \mu$.

${ }^{17} \mu, \dot{\mu}$ and $F_{x}$ are all current values, and $r$ and $g_{x}$ are interest rates. Note that $\dot{x}=g(x, u)$ implies $\partial \dot{x} / \partial x=g_{x}$. 


\section{$\underline{\text { References }}$}

Allen, R.G.D. 1938. Mathematical Analysis for Economists. New York: St. Martin's Press.

Bellman, R.E. 1957. Dynamic Programming. Princeton: Princeton University Press. 1984. Eye in the Hurricane. Singapore: World Scientific Publishing Company.

Bellman, R.E. and S.E. Dreyfus. 1962. Applied Dynamic Programming. Princeton: Princeton University Press.

Blanchard, O.J. and S. Fischer. 1989. Lectures on Macroeconomics. Cambridge, MA: MIT Press.

Conrad, J.M. 1999. Resource Economics. Cambridge: Cambridge University Press.

Cooley, T.F., ed., 1995, Frontiers of Business Cycle Research. Princeton: Princeton University Press.

Dorfman, R. 1969. The Economic Interpretation of Optimal Control Theory. American Economic Review 59, 817-831.

Dreyfus, S. 2002. Richard Bellman on the Birth of Dynamic Programming. Operations Research 50, 48-51.

Hotelling, H. 1931. The Economics of Exhaustible Resources. Journal of Political Economy 39, 137-175.

Keynes, J.M. 1936. The General Theory of Employment, Interest, and Money. (First Harbinger Edition. 1964.) New York: Harcourt, Brace \& World.

Nævdal, E. 2003. Solving Continuous-Time Optimal Control Problems with a Spreadsheet. Journal of Economic Education 34, 99-122.

Pontryagin, L.S., V.G. Boltyanksii, R.V. Gamkrelidze, and E.F. Mishchenko. 1962. The Mathematical Theory of Optimal Processes (Translated by K.N. Trirogoff) New York: John Wiley.

Ramsey, F.P. 1928. A Mathematical Theory of Saving. Economic Journal 38, 543-559.

Walsh, C.E. 2003. Monetary Theory and Policy. Cambridge, MA: MIT Press. 